Чеверда А. Аналіз стану біогеометричного профілю постави дітей, які займаються спортивними танцями. Теорія і методика фрізичного виховання і спорту. 2020; 1: 99-103

DOI: $10.32652 /$ tmfvs.2020.1.99-103

\title{
АНАЛІЗ СТАНУ БІОГЕОМЕТРИЧНОГО ПРОФІЛЮ ПОСТАВИ ДІТЕЙ, ЯКІ ЗАЙМАЮТЬСЯ СПОРТИВНИМИ ТАНЦЯМИ
}

\section{Анастасія Чеверда \\ Національний університет фізичного виховання і спорту України, Київ, Україна}

Анотація. На сьогодні порушення постави - одне з найпоширеніших захворювань опорно-рухового апарату, що веде до виникнення ряду розладів здоров'я дітей. Мета. Здійснити аналіз стану біогеометричного профілю постави дітей 5-6 років, які займаються спортивними танцями. Методи. Теоретичний аналіз спеціальної науково-методичної літератури та документальних матеріалів, метод візуального аналізу, статистична обробка емпіричних даних. Результати. У дослідженні стану біогеометричного профілю постави взяли участь 30 дітей п'яти років та 35 дітей шести років, які займаються спортивними танцями. За допомогою статистичної обробки емпіричних даних було визначено окремі особливості стану біогеометричного профілю постави дітей залежно від статі.

Виявлено, що оцінка стану біогеометричного профілю постави дітей п'яти років у сагітальній площині практично збігається з показником дітей шести років: різниця між середнім значенням показника становить 0,05 \%, а саме 10,$171 ; 2,02$ бала в шість років проти 10,167; 2,02 бала в п'ять років. У фронтальній площині показник дітей п'яти років перевищує аналогічний показник шестирічних дітей на 3,19 \%, де середньостатистичне значення п'ятирічних дітей становило 8,5; 1,96 бала, а в шість років - 8,23; 1,61 бала. Відповідно й загальна оцінка стану біогеометричного профрілю постави у п'ятирічному віці більша на 1,43 \% порівняно з даними дітей шести років. I хоча статистично значущого ( $>>0,05)$ зменшення оцінки стану біогеометричного профрілю постави з віком довести не вдалось, проте можна помітити наявність негативної тенденції до зниження досліджуваного показника, що обумовлено погіршенням постави дітей, що може призвести до подальшого зниження його рівня й спровокувати захворювання опорно-рухового апарату. Встановлено, що на сьогодні існує необхідність застосування дієвих засобів профілактики порушень постави в процесі організації оздоровчої діяльності дітей дошкільного віку, де спортивні танці можуть застосовуватися як ефективні засоби профілактики порушень постави.

Ключові слова: діти п'яти-шести років, оздоровча діяльність, спортивні танці, біогеометричний профіль постави.

\section{Anastasiia Cheverda \\ ANALYSIS OF THE BIOGEOMETRIC PROFILE STATE OF THE POSTURE OF CHILDREN ENGAGED IN SPORTS DANCES}

\begin{abstract}
Today, posture disorders are one of the most common diseases of the locomotorium, leading to a number of health disorders in children. Objective. To analyze the state of the biogeometric profile of the posture of children aged 5-6 years engaged in sports dances. Methods. Theoretical analysis of special scientific and methodical literature and documentary materials, method of visual analysis, statistical processing of empirical data. Results. The study of the state of the posture biogeometric profile involved 30 five-year-old children and 35 six-year-old children engaged in sports dancing. With the help of statistical processing of empirical data, some features of the state of the biogeometric profile of children's posture depending on gender were determined.

It was found that the assessment of the state of the posture biogeometric profile of five-year-olds in the sagittal plane almost coincides with that of six-year-olds: the difference between the average values of the index is $0.05 \%$, namely 10,$171 ; 2,02$ points in six years against 10,$167 ; 2,02$ points in five years. In the frontal plane, the index of five-year-olds is $3,19 \%$ higher than that of six-year-olds, where the average value of five-year-olds was 8,$5 ; 1,96$ points, and at the age of six 8,$23 ; 1,61$ points. Accordingly, the overall assessment of the posture biogeometric profile at the age of five is $1.43 \%$ higher than in six-year-olds. Although it was not possible to prove a statistically significant $(p>0.05)$ decrease in the assessment of the state of the posture biogeometric profile with age, it is possible to notice a negative tendency to decrease of the studied index due to deterioration of children's posture, which can further reduce its level and provoke diseases of the locomotorium. It is established that today there is a need to use effective means of preventing posture disorders in the process of organization of health activities for preschool children, where sports dances can be used as effective means of posture disorders prevention.
\end{abstract}

Keywords: children aged five to six, health activities, sports dances, biogeometric posture profile. 
Вступ. Порушення постави є одним з найпоширеніших захворювань опорно-рухового апарату (OPA) у дітей $[1,2,4,10]$. Наявність подібних захворювань створює сприятливі умови для виникнення ряду інших функціональних і морфологічних розладів здоров'я в дитинстві, що так само чинять негативний вплив на перебіг багатьох захворювань у дорослих [4]. За деякими даними, кількість дітей 3 порушеннями постави сягає 30-60\% [4, 5, 8]. Для відновлення правильної постави дітям призначаються профілактичні заходи, що дозволяє сформувати повноцінний м'язовий корсет та виробити правильний функціональний стереотип [9]. Корекція порушень постави у дітей повинна відбуватися якомога раніше і бути комплексною. Аналіз спеціальної науково-методичної літератури свідчить, що використання фізичних вправ широко застосовується у профілактиці порушень постави, особливо дитячого контингенту [1-5, 7-10].

Спортивні танці на сьогодні є популярним видом рухової активності серед дитячого контингенту [6]. Як зазначають науковці, особливо позитивно вони впливають на стан біогеометричного профілю постави дітей [6]. Тому спеціалісти наголошують на тому, що заняття спортивними танцями можуть значно покращити поставу у дітей п'ятишести років. Проте наявна інформація про результатвиність використання елементів спортивних танців у покращенні біогеометричного профілю постав дітей старшого дошкільного віку недостатньо обгрунтована, що обумовило актуальність подальших досліджень.

Дослідження проведено відповідно до плану науково-дослідної роботи НУФВСУ на 20162020 рр. згідно з темою кафедри здоров'я, фітнесу та рекреації «Теоретико-методологічні засади оздоровчо-рекреаційної рухової активності різних груп населення» (номер держреєстрації 0116U001630).

Мета дослідження - здійснити аналіз стану біогеометричного профілю постави дітей п' яти-шести років, які займаються спортивними танцями.

Методи дослідження: теоретичний аналіз спеціальної науково-методичної літератури та документальних матеріалів, метод візуального аналізу, статистична обробка емпіричних даних.

Результати дослідження та їх обговорення. У дослідженні взяли участь 30 дітей п'яти років та 35 дітей шести років, які займаються спортивними танцями. За допомогою статистичної обробки емпіричних даних було визначено особливості стану біогеометричного профілю їхньої постави залежно від статі.3 огляду на той факт, що порушення постави набувають усе більшого поширення у дітей п'яти-шести років [4, 9] та враховуючи визначені мотиваційні пріоритети батьків щодо занять з елементами спортивного танцю оздоровчої спрямованості їхніх дітей, де серед здоров'ятвірних та естетичних мотивів вирішення проблеми профілактики порушень опорно-рухового апарату займають провідні позиції [4], в ході дослідження здійснено аналіз стану біогеометричного профілю постави дітей, які займаються спортивними танцями. Зауважимо, що з цією метою було використано метод візуального аналізу, який тривалий час ефективно застосовується для масових обстежень дітей і зарекомендував себе як простий та інформативний метод оцінювання постави [3, 4].

Статистична обробка емпіричних даних [4] засвідчила зниження показників стану біогеометричного профілю постави дітей п'яти-шести років, які займаються спортивними танцями. Серед дівчат п'яти років максимальне значення, яке становило 2,12; 0,33 бала, виявлено за показником кута нахилу тулуба, а мінімальні значення зафіксовано за показниками кута в колінному суглобі 1,$53 ; 0,51$ бала та симетричності надпліч - 1,53; 0,62 бала. Як і в дівчат, максимальний показник хлопчиків у 2,08; 0,28 бала зареєстровано за показником кута нахилу тулуба, а мінімальне значення - 1,38; 0,51 бала - за кутом нахилу голови (табл. 1).

Дослідження дозволило виявити окремі особливості стану біогеометричного профілю постави дітей п'яти років залежно від статі. Так, у хлопчиків, порівняно з дівчатками, переважать середні значення таких показників у сагітальній площині:

- живіт, відстань $1_{2}$ - на 2,75 \%;

- кут у колінному суглобі - на 15,68 \%;

у фронтальній площині:

- положення тазових кісток - на 8,97 \%;

- симетричність надпліч - на 10,65 \%;

- симетричність нижніх кутів лопаток - на $6,55 \%$.

Разом з тим, дівчатка мають підвищене значення показників порівняно з хлопчиками у сагітальній площині:

- кут нахилу голови - на 15,93\%;

- грудний кіфоз - на 1,92 \%;

- кут нахилу тулуба - на 1,92\%;

- поперековий лордоз - на 6,59\%;

у фронтальній площині:

- трикутники талії - на 1,92\%;

- постановка стоп - на 2,98\%.

Незважаючи на представлені відмінності, їх статистичну значущість ( $>$ > 0,05) довести не вдалось. Що стосується дітей шести років, то у дівчаток максимальні результати спостерігалися за кутом нахилу тулуба, значення якого становило 1,$78 ; 0,60$ бала та положенням тазових кісток 1,$78 ; 0,42$ бала, а найменші результати в 1,$43 ; 0,51$ бала спостерігалися за постановкою стоп. При цьому у хлопчиків найбільш високим балом $(2,0$; $0,74)$ оцінено кут нахилу тулуба, а найменшим 1,42; 0,51 також за постановкою стоп (табл. 2).

Встановлено, що у хлопчиків середні значення перевищують такі показники стану біогеометричного профілю постави дівчаток, як:

у сагітальній площині:

- грудний кіфоз - на 8,12 \%; 
Таблиця 1 - Показники стану біогеометричного профілю постави дітей п'яти років, які займаються спортивними танцями $(n=30)$, бал

\begin{tabular}{|c|c|c|c|c|c|c|c|c|c|c|c|c|}
\hline \multirow{3}{*}{\multicolumn{2}{|c|}{ Площина }} & \multirow{3}{*}{$\begin{array}{c}\text { Показники біогеометричного } \\
\text { профілю постави дітей }\end{array}$} & \multicolumn{10}{|c|}{ Середньостатистичні дані } \\
\hline & & & \multicolumn{5}{|c|}{ Дівчатка, n = 17} & \multicolumn{5}{|c|}{ Хлопчики, $\mathrm{n}=13$} \\
\hline & & & $\overline{\boldsymbol{x}}$ & Me & $25 \%$ & $75 \%$ & $\mathbf{S}$ & $\overline{\boldsymbol{x}}$ & Me & $25 \%$ & $75 \%$ & $\mathbf{s}$ \\
\hline \multirow{6}{*}{\multicolumn{2}{|c|}{ Сагітальна }} & Кут нахилу голови $\left(\alpha_{1}\right)$ & 1,65 & 2,0 & 1,0 & 2,0 & 0,61 & 1,38 & 1,0 & 1,0 & 2,0 & 0,51 \\
\hline & & Грудний кіфоз (відстань І 1 ) & 1,65 & 2,0 & 1,0 & 2,0 & 0,49 & 1,62 & 2,0 & 1,0 & 2,0 & 0,51 \\
\hline & & Кут нахилу тулуба $\left(\alpha_{2}\right)$ & 2,12 & 2,0 & 2,0 & 2,0 & 0,33 & 2,08 & 2,0 & 2,0 & 2,0 & 0,28 \\
\hline & & Живіт (відстань І 2 ) & 1,65 & 2,0 & 1,0 & 2,0 & 0,49 & 1,69 & 2,0 & 1,0 & 2,0 & 0,48 \\
\hline & & $\begin{array}{l}\text { Поперековий лордоз (від- } \\
\text { стань } \text { I }_{3} \text { ) }\end{array}$ & 1,65 & 2,0 & 1,0 & 2,0 & 0,61 & 1,54 & 1,0 & 1,0 & 2,0 & 0,66 \\
\hline & & Кут у колінному суглобі $\left(\alpha_{3}\right)$ & 1,53 & 2,0 & 1,0 & 2,0 & 0,51 & 1,77 & 2,0 & 1,0 & 2,0 & 0,60 \\
\hline \multirow{5}{*}{$\begin{array}{l}\text { Фрон- } \\
\text { тальна }\end{array}$} & $\begin{array}{l}\text { Вигляд } \\
\text { спереду }\end{array}$ & $\begin{array}{l}\text { Положення тазових кіс- } \\
\text { ток }\left(\alpha_{4}\right)\end{array}$ & 1,76 & 2,0 & 1,0 & 2,0 & 0,66 & 1,92 & 2,0 & 2,0 & 2,0 & 0,64 \\
\hline & \multirow{4}{*}{$\begin{array}{l}\text { Вигляд } \\
\text { ззаду }\end{array}$} & Симетричність надпліч $\left(\alpha_{5}\right)$ & 1,53 & 1,0 & 1,0 & 2,0 & 0,62 & 1,69 & 2,0 & 1,0 & 2,0 & 0,63 \\
\hline & & Трикутники талії & 1,65 & 2,0 & 1,0 & 2,0 & 0,61 & 1,62 & 2,0 & 1,0 & 2,0 & 0,65 \\
\hline & & $\begin{array}{l}\text { Симетричність нижніх кутів } \\
\text { лопаток }\left(\alpha_{6}\right)\end{array}$ & 1,59 & 2,0 & 1,0 & 2,0 & 0,62 & 1,69 & 2,0 & 1,0 & 2,0 & 0,48 \\
\hline & & Постановка стоп & 1,82 & 2,0 & 1,0 & 2,0 & 0,64 & 1,77 & 2,0 & 1,0 & 2,0 & 0,73 \\
\hline
\end{tabular}

Таблиця 2 - Показники стану біогеометричного профілю постави дітей шести років, які займаються спортивними танцями $(n=35)$, бал

\begin{tabular}{|c|c|c|c|c|c|c|c|c|c|c|c|}
\hline \multirow{3}{*}{ Площина } & \multirow{3}{*}{$\begin{array}{c}\text { Показники біогеометричного } \\
\text { профілю постави дітей }\end{array}$} & \multicolumn{10}{|c|}{ Середньостатистичні дані } \\
\hline & & \multicolumn{5}{|c|}{ дівчатка, $n=23$} & \multicolumn{5}{|c|}{ хлопчики, n = 12} \\
\hline & & $\overline{\boldsymbol{x}}$ & Me & $25 \%$ & $75 \%$ & $\mathbf{S}$ & $\bar{x}$ & Me & $25 \%$ & $75 \%$ & $\mathbf{S}$ \\
\hline \multirow[t]{6}{*}{ Сагітальна } & Кут нахилу голови $\left(\alpha_{1}\right)$ & 1,74 & 2,0 & 1,0 & 2,0 & 0,54 & 1,67 & 2,0 & 1,0 & 2,0 & 0,65 \\
\hline & Грудний кіфоз (відстань І & 1,70 & 2,0 & 1,0 & 2,0 & 0,56 & 1,83 & 2,0 & 1,5 & 2,0 & 0,58 \\
\hline & Кут нахилу тулуба $\left(\alpha_{2}\right)$ & 1,78 & 2,0 & 1,0 & 2,0 & 0,60 & 2,00 & 2,0 & 1,5 & 2,5 & 0,74 \\
\hline & Живіт (відстань І 2 ) & 1,52 & 2,0 & 1,0 & 2,0 & 0,51 & 1,75 & 2,0 & 1,0 & 2,0 & 0,62 \\
\hline & $\begin{array}{l}\text { Поперековий лордоз (від- } \\
\text { стань } \text { I }_{3} \text { ) }\end{array}$ & 1,57 & 2,0 & 1,0 & 2,0 & 0,51 & 1,75 & 2,0 & 1,0 & 2,0 & 0,62 \\
\hline & Кут у колінному суглобі $\left(\alpha_{3}\right)$ & 1,65 & 2,0 & 1,0 & 2,0 & 0,49 & 1,58 & 2,0 & 1,0 & 2,0 & 0,51 \\
\hline \multicolumn{12}{|l|}{ Фронтальна } \\
\hline $\begin{array}{l}\text { Вигляд спе- } \\
\text { реду }\end{array}$ & Положення тазових кісток $\left(\alpha_{4}\right)$ & 1,78 & 2,0 & 2,0 & 2,0 & 0,42 & 1,92 & 2,0 & 2,0 & 2,0 & 0,51 \\
\hline \multirow[t]{4}{*}{ Вигляд ззаду } & Симетричність надпліч $\left(\alpha_{5}\right)$ & 1,57 & 2,0 & 1,0 & 2,0 & 0,59 & 1,67 & 2,0 & 1,0 & 2,0 & 0,49 \\
\hline & Трикутники талії & 1,57 & 1,0 & 1,0 & 2,0 & 0,66 & 1,75 & 2,0 & 1,0 & 2,0 & 0,75 \\
\hline & $\begin{array}{l}\text { Симетричність нижніх кутів } \\
\text { лопаток }\left(\alpha_{6}\right)\end{array}$ & 1,70 & 2,0 & 1,0 & 2,0 & 0,63 & 1,83 & 2,0 & 2,0 & 2,0 & 0,39 \\
\hline & Постановка стоп & 1,43 & 1,0 & 1,0 & 2,0 & 0,51 & 1,42 & 1,0 & 1,0 & 2,0 & 0,51 \\
\hline
\end{tabular}

- кут нахилу тулуба - на 12,20 \%;

- живіт (відстань 1 ${ }_{2}$ ) - на 15,00 \%;

- поперековий лордоз - на 11,81%; у фронтальній площині:

- положення тазових кісток - на 7,52 \%;

- симетричність надпліч - на 4,68 \%; 


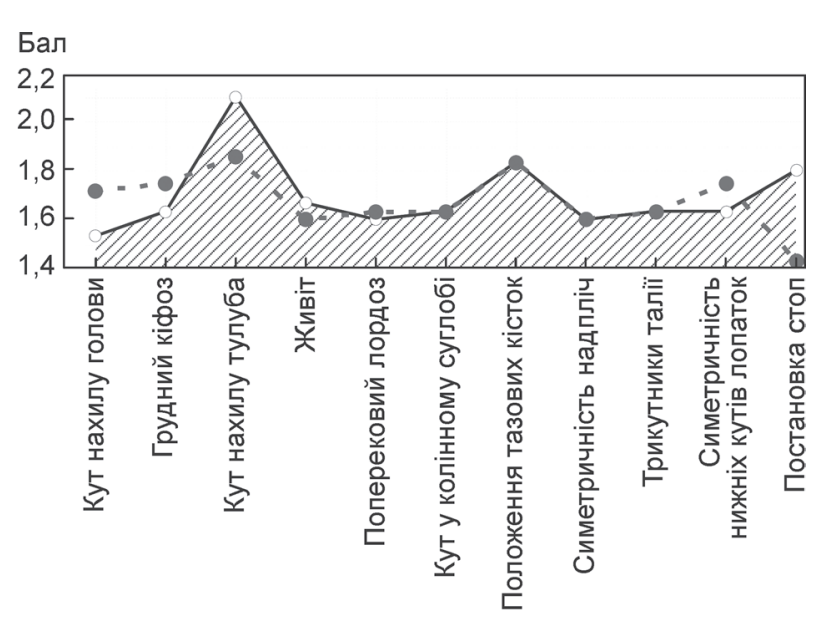

Рисунок 1 - Порівняльний аналіз показників стану біогеометричного профілю постави дітей п'яти-шести років залежно від віку $(\mathrm{n}=65)$

- 5 років; $\multimap-6$ років

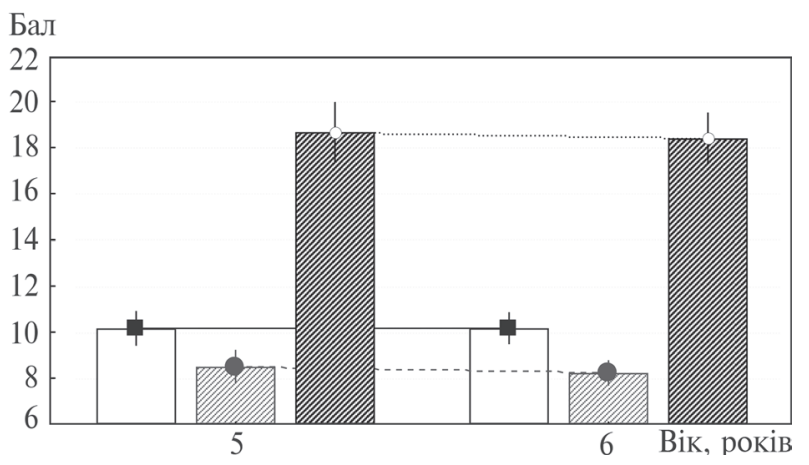

Рисунок 2 - Порівняльний аналіз оцінки стану біогеометричного профілю постави дітей п'яти-шести років залежно від віку $(\mathrm{n}=65)$

E- сагітальна площина; - фронтальна площина; - оцінка стану біогеометричного профілю постави

- трикутники талії - на 11,81\%;

- симетричність нижніх кутів лопаток - на 8,12\%.

Дівчатка мають вищі значення показників порівняно з хлопчиками:

у сагітальній площині:

- кут нахилу голови - на 4,17 \%;

- кут у колінному суглобі - на 4,17 \%;

у фронтальній площині:

- постановка стоп - на 1,26\%.

Попри окремі розходження за тими чи іншими показниками стану біогеометричного профілю постави залежно від статі, статистично значущих $(\mathrm{p}>0,05)$ відмінностей не встановлено. Шляхом співвіднесення вихідних даних дітей залежно від віку виявлено, що окремі показники стану біогеометричного профілю постави дітей шести років знизилися порівняно з дітьми п'яти років. Зокрема, найбільш помітним виявилося зменшення кута нахилу голови, яке становило 11,80 \%. Разом 3 тим помітно зросли значення показників «постановка стоп» та «кут нахилу тулуба» (рис. 1).
Проте, як і у випадку порівняння показників дітей за статтю, між показниками дітей за віком статистично значущих ( $>>0,05)$ відмінностей не зафіксовано. У процесі статистичного аналізу досліджуваних показників виявлено, що оцінка стану біогеометричного профілю постави дітей п'яти років у сагітальній площині практично збігається 3 показником дітей шести років: різниця між середнім значенням показника становить 0,05 \%, а саме 10,$171 ; 2,02$ бала в шість років проти 10,167; 2,02 бала у п'ять років. У фронтальній площині показник дітей п'яти років перевищує аналогічний показник шестирічних дітей на 3,19 \%, де середньостатистичне значення п'ятирічних дітей становило 8,5; 1,96 бала, а в шість років - 8,23; 1,61 бала. Відповідно й загальна оцінка стану біогеометричного профілю постави в п'ятирічному віці більша на 1,43 \% порівняно 3 даними дітей шести років. I хоча статистично значущого ( $p>0,05)$ зменшення оцінки стану біогеометричного профілю постави 3 віком довести не вдалось, проте можна помітити наявність негативної тенденції до зниження досліджуваного показника, що обумовлено погіршенням постави дітей та може призвести до подальшого зниження рівня стану біогеометричного профілю їхньої постави й спровокувати захворювання опорно-рухового апарату (рис. 2).

3 огляду на ситуацію, що склалася зі станом опорно-рухового апарату дітей, важливо до програми занять спортивними танцями включити профілактичні засоби, які разом з основними сприяли б профілактиці та корекції порушень постави дітей старшого дошкільного віку.

Висновки. Отримані результати свідчать про нагальну необхідність застосування дієвих засобів профілактики порушень постави у процесі організації оздоровчої діяльності дітей дошкільного віку, де спортивні танці можуть застосовуватися як ефективні засоби профілактики. Досліджуючи спортивні танці як вид рухової активності, можна стверджувати, що вони мають значний позитивний вплив на стан біогеометричного профілю постави тих, хто займається, а використання фітнес-програм 3 елементами спортивних танців дозволить залучити до занять більший контингент дітей.

Перспективи подальших досліджень полягають у вдосконаленні фітнес-програми 3 елементами спортивних танців, спрямованої на корекцію порушень постави дітей п'яти-шести років та формуванню банку вправ, що сприятимуть закріпленню навички правильної постави під час стояння, сидіння, ходьби, бігу, виконання фізичних вправ; зміцненню м’язового корсета, необхідного для утримання правильної постави; підвищенню рухливості суглобів і хребта; закріпленню вміння управляти своїм тілом у просторі.

Конфлікт інтересів. Автор заявляє, що відсутній будь-який конфлікт інтересів. 


\section{Література}

1. Андрєєва О, Сухомлинов Р. Організація оздоровчо-рекреаційної рухової активності дітей дошкільного віку в умовах клубних занять. Теорія і методика фрізичного виховання і спорту. 2016; 3: 29-32.

2. Андрєєва ОВ, Чернявський МВ. Оцінка доцільності впровадження рекреаційно-оздоровчих технологій в процес фрізичного виховання молодших школярів. Спортивний вісник Придніпров'я. 2009; 2-3: 17-19.

3. Гончарова Н, Денисова Л, Усиченко В. Використання сучасних інформаційних технологій у сфері оздоровчого фрітнесу. Фізичне виховання, спорт і культура здоров’я у сучасному суспільстві. 2012: 163-7.

4. Кашуба В, Носова Н, Коломиец Т, Козлов Ю. Контроль состояния биогеометрического профиля осанки человека в процессе занятий фризическими упражнениями. Спортивний вісник Придніпров'я. 2017. 2: 183-9.

5. Москаленко Н, Полякова А, Ковров Я. Сучасні підходи до організації фрізкультурно-оздоровчої роботи у дошкільних закладах. Спортивний вісник Придніпров'я. 2013; 1: 40-42.

6. Рожкова ТА. Корекція порушень постави спортсменів високої кваліфікації у спортивних танцях засобами фрізичної реабілітації [автореферат]. Київ, 2016. 22 с.

7. Сухомлинов Р, Андрєєва О. Особливості клубної форми організації рекреаційно-оздоровчих занять дітей дошкільного віку. Молодіжний вісник Східноєвропейського національного державного університету. 2017; 25: 67-71.

8. Сухомлинов РО, Андрєєва ОВ. Характеристика показників фрізичного розвитку хлопчиків 5-6 років, які займаються у дитячих футбольних клубах. Науковий часопис НПУ ім. М. П. Драгоманова. Серія 15: Науковопедагогічні проблеми фрізичної культури (Фізична культура і спорт). 2017; 7(89): 35-8.

9. Футорний СМ, Носова НЛ, Коломієць ТВ, Бишевець НГ. Стан проблеми формування та корекції постави дітей 5-6 років. Journal of Education, Health and Sport, 2017; 7. 3: 803-18.

10. Andrieieva OV, Sainchuk OM. Approach to evaluating health level and adaptation possibilities in schoolchildren. Pedagogics, psychology, medical-biological problems of physical training and sports. 2014. 2,3-8.

\section{Literature}

1. Andreieva O, Sukhomlynov R. Organization of health-recreational motor activity of preschool children in the conditions of club classes. Teoriia i metodyka fizvykhovannia i sportu. 2016; 3: 29-32.

2. Andreieva OV, Cherniavskyi MV. Evaluation of the feasibility of introducing recreational and health technologies in the process of physical education of primary school children. Sportyvnyi visnyk Prydniprovia. 2009; 2-3: 17-19.

3. Honcharova N, Denysova L, Usychenko V. Use of modern information technologies in the field of health fitness. Fizychne vykhovannia, sport i kultura zdorovia u suchasnomu suspilstvi. 2012: 163-7.

4. Kashuba V, Nosova N, Kolomiyets T, Kozlov Y. Monitoring the state of the biogeometric profile of human posture during exercise. Sportyvnyi visnyk Prydniprovia. 2017. 2: 183-9.

5. Moskalenko N, Poliakova A, Kovrov I. Modern approaches to organization of physical culture and health work in preschool institutions. Sportyvnyi visnyk Prydniprovia. 2013; 1: 40-42.

6. Rozhkova TA. Correction of posture disorders of elite athletes in sport dances by means of physical rehabilitation [author's abstract]. Kyiv, 2016. 22 p.

7. Sukhomlynov R, Andreieva O. Features of the club form of organization of recreational and health classes for preschool children. Molodizhnyi visnyk Східноєвропейського національного державного університету. 2017; 25: 67-71.

8. Sukhomlynov RO, Andreieva OV. Characteristics of physical development indices of boys aged 5-6 years engaged in children's football clubs. Naukovyi chasopys Natsionalnoho pedahohichnoho universytety imeni M. P. Drahomanova. 2017; 7(89): 35-8.

9. Futornyi SM, Nosova NL, Kolomiiets TV, Byshevets NH. The state of the problem of formation and correction of posture of children 5-6 years. Journal of Education, Health and Sport, 2017; 7. 3: 803-18.

10. Andrieieva OV, Sainchuk OM. Approach to evaluating health level and adaptation possibilities in schoolchildren. Pedagogics, psychology, medical-biological problems of physical training and sports. 2014. 2,3-8.

Надійшла 21.02.2020

\section{Інформація про автора}

Чеверда Анастасія Олегівна https://orcid.org/0000-0001-9426-6608 trofimo4ka92@gmail.com

Національний університет фізичного виховання і спорту України, 03150, Київ, вул. Фізкультури, 1.
Information about the author

Cheverda Anastasiia

https://orcid.org/0000-0001-9426-6608

trofimo4ka92@gmail.com

National University

of Ukraine on Physical Education and Sport,

03150, Kyiv, Fizkul'tury str., 1. 